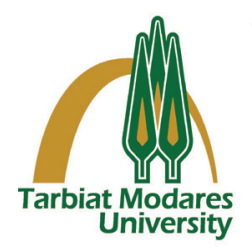

\title{
Association between Chlamydia trachomatis Infection and Prostate Cancer: A Case-Control Study
}

\section{A R T I C L E I N F O}

Article Type

Original Research

\section{Authors}

Neda Baseri $M S c^{1,2,3^{*}}$

Gita Eslami, $P h D^{1}$

Zohreh Ghalavand, $P h D^{1}$

Hanieh Zham, $P h D^{4}$

Eznollah Azargashb, $P h D^{5}$

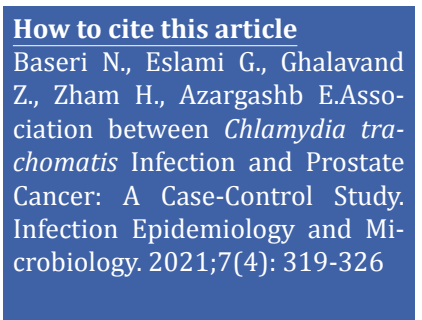

${ }^{1}$ Department of Microbiology, School of Medicine, Shahid Beheshti University of Medical Sciences, Tehran, Iran ${ }^{2}$ Department of Epidemiology and Biostatistics, Research Center for Emerging and Reemerging infectious diseases, Pasteur Institute of Iran, Tehran, Iran ${ }^{3}$ National Reference laboratory for Plague, Tularemia and Q fever, Research Center for Emerging and Reemerging infectious diseases, Pasture Institute of Iran, Akanlu, Kabudar Ahang, Hamadan, Iran ${ }^{4}$ Cancer research center, Shohada-e Tajrishh Hospital, Shahid Beheshti University of Medical Sciences, Tehran, Iran ${ }^{5}$ Department of community Medicine and Heaith, school of medicine, Shahid Beheshti University of Medical Sciences, Tehran, Iran

\section{* Correspondence}

Address: Department of Microbiology, School of Medicine, Shahid Beheshti University of Medical Sciences, Tehran, Iran

nedabaseri@modares.ac.ir

\section{Article History}

Received: October 052021

Accepted: August 17,2021

Published: November 25,2021

\section{A B S T R A C T}

Background: Evidence indicating the association of cancers and chronic inflammations is increasing. The importance of urinary tract and sexually transmitted infections (UTIs and STIs) in the development of prostate cancer is still unclear. Chlamydia trachomatis (C. trachomatis) is one of the most important causes of UTIs and STIs. Here, a case-control study was performed on the Iranian population to assess the association between $C$. trachomatis and prostate cancer (PC). Materials \& Methods: Paraffin-embedded prostate tissue specimens collected from 62 PC and $62 \mathrm{PBH}$ (benign prostate hyperplasia) (as controls) patients were screened to detect $C$. trachomatis 16srRNA gene using nested polymerase chain reaction (nested PCR) method. A $p$-value $<.05$ was interpreted as a remarkable difference using SPSS statistical software Ver. 16. Findings: There was a significant difference regarding the prevalence of $C$. trachomatis $(p<$ .001; OR=10.07; 95\% CI [2.81-36.001]) between the PC (33.87\%) and BPH (4.84\%) samples. Furthermore, prostate-specific antigen (PSA) levels were statistically higher $(p<.05)$ in $C$. trachomatis-positive patients than in patients with negative $C$. trachomatis.

Conclusion: It could be concluded that patients with a history of $C$. trachomatis infections are more likely to develope PC. Therefore, early diagnosis and treatment of $C$. trachomatis infection may help the prevention of PC. Moreover, nested PCR is a suitable method for C. trachomatis detection in paraffin-embedded prostate tissue specimens.

\section{Keywords: Prostate cancer, Chlamydia trachomatis, Benign prostatic hyperplasia,} Sexually transmitted infections.

\section{CITATION LINKS}

[1] Haas GP, Delongchamps N, Brawley ... [2] Bracarda S, De Cobelli O, Greco C, Prayer-Galetti T, Valdagni R, Gatta G, et al. Cancer of... [3] Coussens LM, Werb Z. Inflammation... [4] De Martel C, Franceschi S. Infections and cancer: Established associations and... [5] Sfanos KS, Isaacs JT. The "infectious" nature of human prostate... [6] Cheng I, Witte JS, Jacobsen SJ, Haque R ... [7] Huang W-Y, Hayes R, Pfeiffer R, Viscidi RP, Lee FK, Wang YF, et al. Sexually... [8] Lipsky BA. Prostatitis and urinary tract infection... [9] Shoskes DA, Altemus J, Polackwich AS, Tucky B, Wang H, Eng C. The urinary... [10] Bajic P, Dornbier RA, Doshi CP, Wolfe AJ, Farooq AV, Bresler L. Implications of the genitourinary... [11] Katongole P, Sande OJ, Joloba M, Reynolds SJ, Niyonzima N. The... [12] Wagenlehner FM, Weidner W, Naber KG. Chlamydial... [13] Witkin SS, Minis E, Athanasiou A, Leizer J, Linhares IM. Chlamydia... [14] Bruce A, Chadwick P, Willett W, O'shaughnessy M. The role of chlamydiae in... [15] Chumduri C, Gurumurthy RK, Zadora PK, Mi Y, Meyer TF. Chlamydia infection... [16]_Koskela P, Anttila T, Bjørge T, Brunsvig A, Dillner J, Hakama M, et al. Chlamydia... [17] Trabert B, Waterboer T, Idahl A, Brenner N, Brinton LA, Butt J, et al. Antibodies against... [18] Archer M, Dogra N, Kyprianou N. Inflammation as... [19] Wang Y-C, Chung C-H, Chen J-H, Chiang M-H, Tsao C-H, Lin F-H, et al. Gonorrhea ... [20] Caini S, Gandini S, Dudas M, Bremer V, Severi E, Gherasim A. Sexually ... [21] Laurila AL, Anttila T, Läärä E, Bloigu A, Virtamo J, Albanes D, et al. Serological ... [22] Abdul-Wahab OMS, Al-Shyarba MH, Mardassi BBA, Sassi N, Al Fayi MSS, Otifi H, et al. Molecular... [23] Korodi Z, Wang X, Tedeschi R, Knekt P, Dillner J. No serological... [24] Eslami G, Goudarzi H, Baseri N, Ghalavand Z, Taherpour A, Zhaam H, et al. The prevalence of Ureaplasma urealyticum and Mycoplasma genitalium in patients with ... [25] Bielecki R, Ostaszewska-Puchalska I, Zdrodowska-Stefanow... [26] Miyake M, Ohnishi K, Hori S, Nakano A, Nakano R, Yano H, et al. Mycoplasma genitalium infection and chronic inflammation in human prostate... [27] Petyaev IM, Zigangirova NA, Morgunova EY, Kyle NH, Fedina ED, Bashmakov YK. Chlamydia trachomatis growth... [28] Yow MA, Tabrizi SN, Severi G, Bolton DM, Pedersen J, Longano A, et al. Detection of ... [29] Sfanos KS, Sauvageot J, Fedor HL, Dick JD, De Marzo AM, Isaacs WB. A molecular... [30] Anttila T, Tenkanen L, Lumme S, Leinonen M, Gislefoss RE, Hallmans G, et al. Chlamydial ... [31] Dillner J, Knekt P, Boman J, Lehtinen M, Af Geijersstam V, Sapp M, et al. Sero-epidemiologal... [32] Dennis LK, Coughlin JA, McKinnon BC, Wells TS, Gaydos... [33] Sutcliffe S, Giovannucci E, Gaydos CA, Viscidi RP... [34] Skibinski G, Kelly R, Harkiss D, James K. Immunosuppression by ... [35] Kelly R. Prostaglandins in... [36] Montecino-Rodriguez E, Berent-Maoz B, Dorshkind K. Causes, consequences, and... 


\section{Introduction}

Prostate cancer (PC) is one of the most prevalent life-threatening malignancies in men worldwide ${ }^{[1]}$. Nevertheless, the causes of PC are not entirely known [2]. Chronic infections are considered to be the cause of at least $20 \%$ of all human cancers. For instance, chronic infection with Helicobacter pylori could induce gastric cancer ${ }^{[3-5]}$.

The prostate gland may be infected by microbial infections, including urinary tract infections (UTIs) and sexually transmitted infections (STIs). Therefore, studies have suggested that chronic inflammations caused by UTIs and STIs may be linked to an increased risk of PC ${ }^{[6-10]}$. On the other hand, some cases of PC have been observed in patients with a history of chronic prostatitis and chronic pelvic pain syndrome (CPPS), which are caused by bacterial infections [11]. The most common bacteria detected in PC patients are Propionibacterium acnes, Mycoplasma genitalium, Enterobacteriaceae spp., and Bacteroides spp. [11].

Chlamydia trachomatis (C. trachomatis) is an obligate intracellular bacterium and one of the most common causes of STIs in the world ${ }^{[12]}$. C. trachomatis could cause asymptomatic and persistent infections [13]. In sexually active men, $C$. trachomatis is the most common cause of nongonococcal urethritis ${ }^{[12]}$. It could also play a role in epididymitis and prostatitis. In women, chronic $C$. trachomatis infections are associated with cervicitis, endometritis, salpingitis, and pelvic inflammatory disease (PID) ${ }^{[14]}$. Furthermore, the role of Chlamydia in promoting the host DNA damage and proliferation and subsequently triggering tumorigenesis has been established. Several studies have revealed that chronic C. trachomatis infections play an important role in the development of cervical and ovarian cancers [15-17]. However, studies on PC are limited and yielded conflicting results due to the use of different detection methods. In this study, the hypothesis that the presence of $C$. trachomatis is associated with PC was investigated using the standard nested polymerase chain reaction method (nested PCR), especially by examining its role in increasing serum prostate-specific antigen (PSA) levels and Gleason scores (GS). Objectives: This case-control study was conducted on patients referring to Shohada hospital (Tehran, Iran) to evaluate the possible role of $C$. trachomatis in the etiology of PC. The presence of $C$. trachomatis DNA was compared in prostate tissue of PC (case group) and $\mathrm{BPH}$ (control group) patients using the nested PCR method.

\section{Materials and Methods}

Study population: The present descriptive case-control study was conducted on formalin-fixed and paraffin-embedded (FFPE) prostate tissue specimens taken from men (50-89 years old) through open prostatectomy, core needle biopsy, and transurethralresection of the prostate(TURP) during 2007-2012 in Shohada hospital in Tehran, Iran. FFPE samples included 62 PC and $62 \mathrm{BPH}$ (controls) cases. The research population characteristics are summarized in Table 1.

Microscopic evaluation of $H \& E$ stained pathological slides of PC patients: For each PC patient, there were several FFPE prostate tissue blocks as well as pathological hematoxylin and eosin-stained (H\&E) slides that matched with blocks.

FFPE blocks and H\&E slides were obtained from different areas of prostate tissue of each PC patient. Therefore, microscopic evaluation of H\&E stained slides was performed by an experienced pathologist to identify cancerous areas (cancerous and non-cancerous tissues differentiation). Ultimately, the best block with the highest percentage of neoplastic cells and cancerous 
Table 1) The study population characteristics.

\begin{tabular}{|c|c|c|}
\hline Characteristic & Prostate Cancer (Cases) & Benign Prostate Hyperplasia (Controls) \\
\hline Total number of patients & 62 & 62 \\
\hline $\begin{array}{l}\text { Mean age (range, years) } \\
<60 \\
60-69 \\
70-79 \\
>79\end{array}$ & $\begin{array}{c}67.8 \pm 7.9(86-50) \\
10(16.13 \%) \\
23(37.1 \%) \\
28(45.16 \%) \\
1(1.61 \%) \\
\end{array}$ & $\begin{array}{c}68 \pm 9.1(40-89) \\
11(17.74 \%) \\
22(35.48 \%) \\
24(38.72 \%) \\
5(8.06 \%)\end{array}$ \\
\hline $\begin{array}{l}\text { Needle biopsy sampling } \\
\text { TURP }{ }^{1} \text { sampling } \\
\text { Prostatectomy sampling }\end{array}$ & $\begin{array}{c}22(35.48 \%) \\
8(12.91 \%) \\
32(51.61 \%)\end{array}$ & $\begin{array}{c}4(6.45 \%) \\
40(64.52 \%) \\
18(29.03 \%)\end{array}$ \\
\hline $\begin{array}{l}\text { Median Gleason Score (range) } \\
\text { 2-5 (low) } \\
\text { 6-7 (intermediate) } \\
\text { 8-10 (high) }\end{array}$ & $\begin{array}{c}6.92 \pm 1.23(5-10) \\
7(11.29 \%) \\
39(62.90 \%) \\
16(25.81 \%)\end{array}$ & $\begin{array}{l}- \\
- \\
-\end{array}$ \\
\hline Presence of PIN ${ }^{2}$ & $11(17.74 \%)$ & - \\
\hline $\begin{array}{l}\text { Mean PSA }{ }^{3}(\mathbf{n g} / \mathbf{m L}) \\
0-4(\mathrm{ng} / \mathrm{mL}) \\
4.1-10(\mathrm{ng} / \mathrm{mL}) \\
10.1-20(\mathrm{ng} / \mathrm{mL}) \\
>20(\mathrm{ng} / \mathrm{mL})\end{array}$ & $\begin{array}{l}19.19 \pm 16.43 \\
3(4.84 \%) \\
19(30.65 \%) \\
22(35.48 \%) \\
18(29.03 \%)\end{array}$ & $\begin{array}{c}4.16 \pm 3.8 \\
38(61.29 \%) \\
19(30.65 \%) \\
5(8.06 \%) \\
0(0 \%)\end{array}$ \\
\hline $\begin{array}{l}{ }^{1} \text { Transurethral resection of the } \mathrm{p} \\
{ }^{2} \text { Prostatic intraepithelial neoplas } \\
{ }^{3} \text { Prostate-specific antigen }\end{array}$ & & \\
\hline
\end{tabular}

tissue was selected from the blocks of each PC patients for future analysis.

Recordofmedicallaboratoryinformation: Demographic and medical information, including age, clinical symptoms (symptomatic or asymptomatic), Gleason score, presence of prostatic intraepithelial neoplasia (PIN), and serum PSA level $(\mathrm{ng} / \mathrm{mL})$, were collected from patients' medical records. This information is displayed in Table 1.

DNA extraction: Genomic DNA was extracted from FFPE prostate tissue samples using G-spin ${ }^{\mathrm{TM}}$ Total DNA Extraction Kit (iNtRON Biotechnology, Korea) according to the manufacturer's instructions. Briefly, FFPE tissues were cut into thin sections using a sterile razor blade. To eliminate DNA cross-contamination between the samples, razor blades were changed for each specimen. Sections (up to $25 \mathrm{mg}$ ) were deparaffinized using xylene. Absolute ethanol and 70\% ethanol were used for xylene elimination and tissue hydration, respectively. After enzymatic digestion with proteinase $\mathrm{K}$, bacterial DNA was extracted from homogenized tissue.

DNA concentration and quality were measured using a NanoDrop (Biochrom WPA Biowave II, UK). DNA samples were maintained at $-20^{\circ} \mathrm{C}$.

Nested PCR: The standard nested PCR assay was carried out to amplify and identify $C$. trachomatis using C. trachomatis nested PCR detection kit (Pars Tous Co., Iran) according to the manufacturer's instructions. The reaction mixtures with a final volum of 20 $\mu \mathrm{L}$ for the first-round PCR contained 14.6 $\mu \mathrm{L}$ of PCR Master Mix 1, 0.4 $\mu \mathrm{L}$ of HS-Taq DNA polymerase, and $5 \mu \mathrm{L}$ of DNA template. Also, $5 \mu \mathrm{L}$ of PCR-grade water and $5 \mu \mathrm{L}$ of standardized positive controls were used as negative and positive controls, respectively. The PCR amplification was performed 
Table 2) Comparison of demographic, clinical, and pathological features between positive and negative $C$. trachomatis infections in prostate cancer patients

\begin{tabular}{|c|c|c|c|}
\hline Characteristic & $\begin{array}{l}\text { Prostate Cancer with } \\
\text { Positive C. trachomatis } \\
(n=21)\end{array}$ & $\begin{array}{l}\text { Prostate Cancer with } \\
\text { Negative C. trachomatis } \\
(n=41)\end{array}$ & P-Value \\
\hline Mean age (range, years) & $68.7 \pm 7.2$ & $67.7 \pm 8.7$ & $>.05$ \\
\hline $\begin{array}{l}\text { Clinical features } \\
\text { Symptomatic } \\
\text { Asymptomatic }\end{array}$ & $\begin{array}{l}14(66.67 \%) \\
7(33.33 \%)\end{array}$ & $\begin{array}{l}29(70.73 \%) \\
12(29.27 \%)\end{array}$ & $>.05$ \\
\hline $\begin{array}{l}\text { Gleason score (range) } \\
2-5 \text { (low) } \\
\text { 6-7 (intermediate) } \\
\text { 8-10 (high) }\end{array}$ & $\begin{array}{l}3(14.29 \%) \\
13(61.90 \%) \\
5(23.81 \%)\end{array}$ & $\begin{array}{l}4(9.76 \%) \\
26(63.41 \%) \\
11(26.83 \%)\end{array}$ & $>.05$ \\
\hline Presence of PIN ${ }^{1}$ & $6(28.57 \%)$ & $5(12.20 \%)$ & $>.05$ \\
\hline
\end{tabular}

${ }^{1}$ Prostatic intraepithelial neoplasia.

under the following conditions: an initial denaturation step at $94{ }^{\circ} \mathrm{C}$ for $10 \mathrm{~min}$, followed by 40 cycles of denaturation at 94 ${ }^{\circ} \mathrm{C}$ for $30 \mathrm{~s}, 55^{\circ} \mathrm{C}$ for $40 \mathrm{~s}$, and $72^{\circ} \mathrm{C}$ for $30 \mathrm{~s}$ and a final extension step at $72^{\circ} \mathrm{C}$ for $5 \mathrm{~min}$. In the second step of amplification, $5 \mu \mathrm{L}$ of the first step products, $14.6 \mu \mathrm{L}$ of PCR Master Mix 2, and $0.4 \mu \mathrm{L}$ of HS-Taq DNA polymerase were used. The annealing temperature for the second step was set at $57^{\circ} \mathrm{C}$. After electrophoresis of PCR products, the presence of 250 base pairs (bp) fragments was considered positive for $C$. trachomatis. Statistical analysis

Data were analyzed using SPSS statistical software Ver. 16 by employing Chi-square test and $t$-test. $P$-values $<.05$ were regarded as a statistically remarkable difference.

\section{Findings}

In the present study, C. trachomatis was detected in 21 (33.87\%) PC (the case group) and 3 (\%4.84) BPH (the control group) samples (Figure 1), and this difference in the prevalence rate of $C$. trachomatis between the two groups was significant $[p<.001$; $\mathrm{OR}=10.07 ; 95 \%$ CI (2.81-36.001)]. In this study, the association between the presence of $C$. trachomatis and age, clinical and pathological features, and PSA levels was investigated in PC patients. The mean PSA value was $17.36 \pm 16.07 \mathrm{ng} / \mathrm{mL}$ in C. trachomatispositive PC patients and $10.31 \pm 13.28 \mathrm{ng} / \mathrm{mL}$ in patients with negative $C$. trachomatis. There was a significant $(p<.05)$ association between the presence of $C$. trachomatis and increased PSA levels in PC patients (Figure 2).

However, there was no significant $(p>.05)$ difference between $C$. trachomatis-positive and C. trachomatis-negative patients in terms of age, symptomatic or asymptomatic clinical signs, Gleason score, and PIN presence (Table 2). In PC patients, the highest rate of $C$. trachomatis infection was detected in TURP specimens; $50 \%$ of TURP specimens were $C$. trachomatis positive. In addition, 36.6 and $28 \%$ of needle biopsy and of prostatectomy specimens were positive, respectively. However, there was no significant difference between different types of sampls regarding the presence of $C$. trachomatis in PC patients.

\section{Discussion}

Since PC has been proposed to be associated with chronic inflammation [18], various studies have confirmed STIs (such as 
gonorrhea and mycoplasma infections) as a risk factor for PC ${ }^{[19-22]}$. However, some studies have found null associations between the two ${ }^{[23,24]}$. On the other hand, Chlamydia as a common cause of STIs could also induce chronic and persistent prostate infections ${ }^{[6}$, 25]. Therefore, there is growing evidence of the role of $C$. trachomatis in PC development.

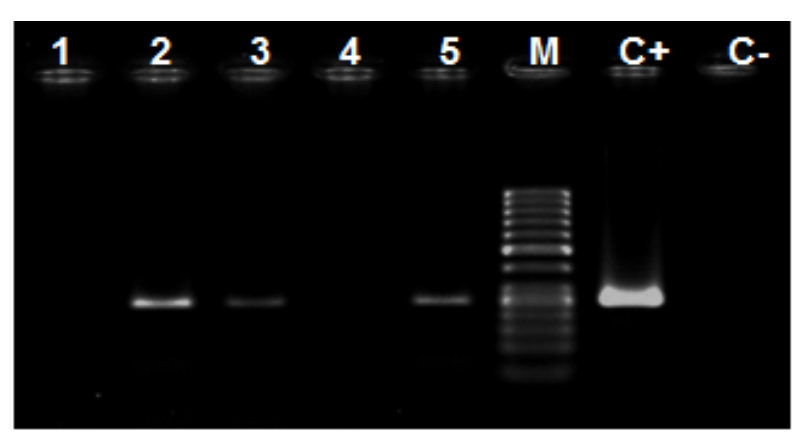

Figure 1) The results of agarose gel electrophoresis using the nested-PCR method for the detection of $16 \mathrm{~s}$ rRNA gene in C. trachomatis. Numbers 1 to 5 indicate nested PCR products of patients (negative, positive, positive, negative, and positive $C$. trachomatis DNA samples, respectively). Sign "M" indicates a $50 \mathrm{bp}$ ladder. "C+" and "C-" indicate positive control (250 bp fragment) and negative control, respectively.

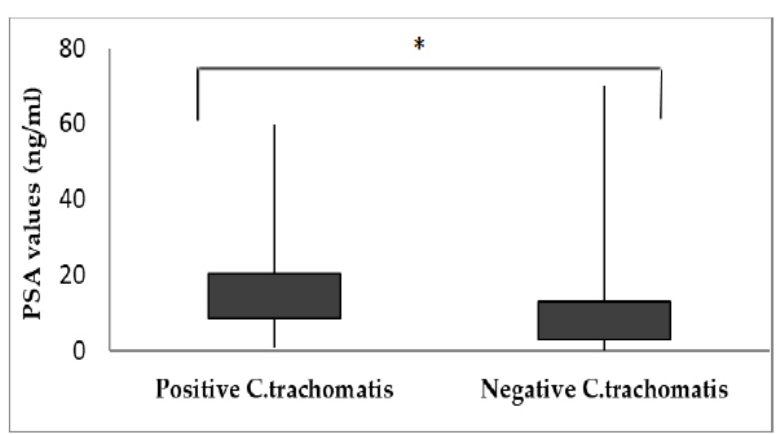

Figure 2) The association between the presence of C. trachomatis and PSA values. PSA levels were higher in C. trachomatis-positive PC patients than in PC patients without C. trachomatis infections. The symbol $(*)$ indicates a significant difference ( $p$ $<.05)$. A p-value $\leq .05$ was regarded as a significant difference between the case (PC) and control (BPH) groups. C. trachomatis: Chlamydia trachomatis; PSA: prostate-specific antigen; PC: prostate cancer; BPH: benign prostate hyperplasia.

In this case-control study, the prevalence of C. trachomatis was investigated in PC and BPH specimens as the case and control groups using the nested-PCR method. The statistical analysis results showed the higher prevalence rate of $C$. trachomatis in PC specimens (33.87\%) than in BPH specimens (4.84\%). Therefore, the association of $C$. trachomatis infection and PC was confirmed in this study. In the present study, PSA levels were significantly higher in C. trachomatispositive PC patients than in those with negative $C$. trachomatis. These findings indicate that $C$. trachomatis in prostate tissue could induce PSA production and increase serum PSA levels.

In a similar study in Japan in 2019, 45 PC and $33 \mathrm{BPH}$ FFPE tissue specimens were screened for the presence of seven STI agents, including $C$. trachomatis, using PCR. In contrast to the present study result, no significant association was found between $C$. trachomatis and PC; however, $M$. genitalium was shown to be associated with PC ${ }^{[26]}$. Recently, a molecular and cell cultur study showed that $C$. trachomatis could efficiently proliferate in a PC cell line and also affect the expression of cytokines related to tumor progression in these cells [27]. However, in a study by Yow et al. (2014), no $C$. trachomatis was detected in 195 FFPE specimens obtained from PC patients using PCR ${ }^{[28]}$. In another study in 2008, only 0.5 $\%$ C. trachomatis was detected in frozen PC biopsies using PCR ${ }^{[29]}$.

A positive association between $\mathrm{PC}$ and $C$. trachomatis was also reported in a cohort self-report study in 2002-2003 (follow-up period 2006) on 1658 PC cases collected from men of different races in California, including African-American, AsianAmerican, Latino, and white. Their race/ ethnicity-stratified analysis showed that PC was associated with a history of chlamydial infection among Asian-American and LatinAmerican men in California ${ }^{6]}$. However, the interpretation of self-report studies results is challenging for some reasons as follows: 
first, chlamydial infections are frequently asymptomatic in men. Therefore, people are sometimes unaware of their disease. Furthermore, conventional methods are less sensitive in detecting asymptomatic $C$. trachomatis infections. Second, self-report studies usually lack accurate and complete information due to some bias.

Most serological studies have not been successful in confirming the positive association between $\mathrm{PC}$ and $C$. trachomatis. In addition, in some retrospective and prospective case-control studies (in Europe and the USA) conducted using serological methods suchasmicro-immunofluorescence, the prevalence of $C$. trachomatis in serum samples of PC patients hasn't been reported to be significant compared with control samples [30-33]. Therefore, this discrepancy between the present and other studies results could be attributed to the use of different detection methods. Immunological mechanisms might explain the lack of a positive association in serological methods. First, prostate tissue secretes proteases, and semen fluid contains large amounts of prostaglandins. These immune-inhibiting molecules may inhibit humoral immune responses and antibody production even in the presence of $C$. trachomatis in prostate tissue [30,34,35]. Second, adenocarcinoma is a common histological type (about 95\%) of PC, and the presence of $C$. trachomatis in prostate adenoid cells prevents the induction of antibody production. In confirmation of this fact, studies have reported an association between increased chlamydial antibody with cervical and lung squamous cell carcinomas, but not with adenocarcinoma types [16, 21]. Third, antibodies produced in older men (those at higher risk of PC incidence) may not be as significant as in young men due to decreased immune function ${ }^{[36]}$. Forth, the sensitivity of different markers in detecting chlamydial infections in prostate tissue may vary. For example, a large case-control prospective study in 2007 on white and black races showed that there was an association between PC in black and the presence of $C$. trachomatis IgA antibodies (anti-HSP60), but not IgG (anti-OMP) [7]. According to the current study results, the nested-PCR method could be considered as a sensitive assay for detecting $C$. trachomatis in FFPE prostate tissue.

In the present research, the highest prevalence rate of $C$. trachomatis infection in PC patients was observed in samples taken through TURP (50\% of TURP, $36.6 \%$ of needle biopsy, and $28 \%$ of prostatectomy samples were positive); however, there was no significant difference regarding the prevalence rate of $C$. trachomatis between different sample types. This result suggests that TURP specimens might be contaminated with $C$. trachomatis due to sampling through the urethra. The urethra is an excretory tube of the urinary bladder and therefore may be infected with $C$. trachomatis.

Finally, various factors could affect the results of studies, including the type of study (self-report, laboratory), detection method (molecular, serological), samples (fresh biopsy, FFPE), and sampling (TURP, prostatectomy, needle biopsy). Therefore, the evidence is still unclear and insufficient, and further studies are required.

\section{Conclusion}

The present study detected a significant difference in terms of $C$. trachomatis prevalence in FFPE prostate tissues between Iranian PC and BPH patients using the nested-PCR method. Therefore, it is suggested that $C$. trachomatis could be involved in PC development. The global prevalence of $C$. trachomatis as a cause of STIs and UTIs, anatomical location of the prostate, and the importance of inflammation in cancer development could support this result. 
Therefore, early diagnosis and treatment of C. trachomatis infections may be useful in the prevention of PC.

\section{Acknowledgments}

We thank the pathology department of Shohada-e Tajrishh Hospital and Shahid Beheshti University of Medical Sciences in Tehran, Iran for providing patients' medical records. We thank the school of medicine of Shahid Beheshti University of Medical Sciences for financing this project.

Ethical Permission: All ethical principles to protect participants' dignity, rights, safety, and well-being were the primary considerations of this research project and were performed according to Shahid Beheshti University of Medical Sciences guidelines.

Conflicts of interests: None.

Authors Contribution: Conceptualization: GS, NB; Methodology: NB, GS, ZG, HZh; Software: AA; Validation: NB, GS, ZGh; Formal analysis: AA; Investigation: NB, HZh; Writing and original draft preparation: NB; Writing, review, and editing: GS; Supervision: GS; Adviser: ZGh.

Fundings: This study was financially sponsored by the school of medicine of Shahid Beheshti University of Medical Sciences, Tehran, Iran. Grant number is not available. Consent to participate: The consent forms were obtained from all patients.

\section{References}

1. Haas GP, Delongchamps N, Brawley OW, Wang CY, de la Roza G. The worldwide epidemiology of prostate cancer: Perspectives from autopsy studies. Can J Urol. 2008;15(1):3866.

2. Bracarda S, De Cobelli O, Greco C, Prayer-Galetti T, Valdagni R, Gatta G, et al. Cancer of the prostate. Crit Rev Oncol Hematol. 2005;56(3):379-96.

3. Coussens LM, Werb Z. Inflammation and cancer. Nature. 2002;420(6917):860-7.

4. De Martel C, Franceschi S. Infections and cancer: Established associations and new hypotheses. Crit Rev Oncol Hematol. 2009;70(3):183-94.

5. Sfanos KS, Isaacs JT. The "infectious" nature of human prostate cancer: A cautionary note.
Oncotarget. 2011;2(4):281-3.

6. Cheng I, Witte JS, Jacobsen SJ, Haque R, Quinn VP, Quesenberry CP, et al. Prostatitis, sexually transmitted diseases, and prostate cancer: The California Men's Health Study. PLoS One. 2010;5(1):e8736.

7. Huang W-Y, Hayes R, Pfeiffer R, Viscidi RP, Lee FK, Wang YF, et al. Sexually transmissible infections and prostate cancer risk. Cancer Epidemiol Biomarkers Prev. 2008;17(9):2374-81.

8. Lipsky BA. Prostatitis and urinary tract infection in men: What's new; what's true? Am J Med. 1999;106(3):327-34.

9. Shoskes DA, Altemus J, Polackwich AS, Tucky B, Wang $\mathrm{H}$, Eng C. The urinary microbiome differs significantly between patients with chronic prostatitis/chronic pelvic pain syndrome and controls as well as between patients with different clinical phenotypes. Urology. 2016;92:26-32.

10. Bajic P, Dornbier RA, Doshi CP, Wolfe AJ, Farooq $\mathrm{AV}$, Bresler L. Implications of the genitourinary microbiota in prostatic disease. Curr Urol Rep. 2019;20(7):1-10.

11. Katongole P, Sande OJ, Joloba M, Reynolds SJ, Niyonzima N. The human microbiome and its link in prostate cancer risk and pathogenesis. Infect Agent Cancer. 2020;15(1):1-8.

12. Wagenlehner FM, Weidner W, Naber KG. Chlamydial infections in urology. World J Urol. 2006;24(1):4-12.

13. Witkin SS, Minis E, Athanasiou A, Leizer J, Linhares IM.Chlamydia trachomatis: Thepersistent pathogen. Clin Vaccine Immunol. 2017;24(10):e00203-17.

14. Bruce A, Chadwick P, Willett W, O'shaughnessy M. The role of chlamydiae in genitourinary disease. J Urol. 1981;126(5):625-9.

15. Chumduri C, Gurumurthy RK,Zadora PK, Mi Y, Meyer TF. Chlamydia infection promotes host DNA damage and proliferation but impairs the DNA damage response. Cell Host Microbe. 2013;13(6):746-58.

16. Koskela P, Anttila T, Bjørge T, Brunsvig A, Dillner J, Hakama M, et al. Chlamydia trachomatis infection as a risk factor for invasive cervical cancer. Int $J$ Cancer. 2000;85(1):35-9.

17. Trabert $B$, Waterboer $T$, Idahl $A$, Brenner $N$, Brinton LA, Butt J, et al. Antibodies against Chlamydia trachomatis and ovarian cancer risk in two independent populations. J Natl Cancer Inst. 2019;111(2):129-36.

18. Archer M, Dogra N, Kyprianou N. Inflammation as a driver of prostate cancer metastasis and therapeutic resistance. Cancers. 2020;12(10):2984.

19. Wang Y-C, Chung C-H, Chen J-H, Chiang M-H, Tsao $\mathrm{C}-\mathrm{H}$, Lin F-H, et al. Gonorrhea infection increases the risk of prostate cancer in Asian population: A nationwide population-based cohort study. Eur J Clin Microbiol Infect Dis. 2017;36(5):813-21.

20. Caini S, Gandini S, Dudas M, Bremer V, Severi E, 
Gherasim A. Sexually transmitted infections and prostate cancer risk: A systematic review and metaanalysis. Cancer Epidemiol. 2014;38(4):329-38.

21. Laurila AL, Anttila T, Läärä E, Bloigu A, Virtamo J, Albanes D, etal. Serological evidence of an association between Chlamydia pneumoniae infection and lung cancer. Int J Cancer. 1997;74(1):31-4.

22. Abdul-Wahab OMS, Al-Shyarba MH, Mardassi BBA, Sassi N, Al Fayi MSS, Otifi H, et al. Molecular detection of urogenital mollicutes in patients with invasive malignant prostate tumor. Infect Agent Cancer. 2021;16(1):1-11.

23. Korodi Z, Wang X, Tedeschi R, Knekt P, Dillner J. No serological evidence of association between prostate cancer and infection with herpes simplex virus type 2 or human herpesvirus type 8: A nested case-control study. J Infect Dis. 2005;191(12):200811.

24. Eslami G, Goudarzi H, Baseri N, Ghalavand Z, Taherpour A, Zhaam $\mathrm{H}$, et al. The prevalence of Ureaplasma urealyticum and Mycoplasma genitalium in patients with prostate cancer in Shohada Hospital in Tehran, Iran. NBM. 2015;3(2):73-8.

25. Bielecki R, Ostaszewska-Puchalska I, ZdrodowskaStefanow B, Baltaziak M,Skawrońska M, Sokołowska $\mathrm{M}$. The presence of Chlamydia trachomatis infection in men with chronic prostatitis. Cent European J Urol. 2020;73(3):362.

26. Miyake M, Ohnishi K, Hori S, Nakano A, Nakano R, Yano $\mathrm{H}$, et al. Mycoplasma genitalium infection and chronic inflammation in human prostate cancer: Detection using prostatectomy and needle biopsy specimens. Cells. 2019;8(3):212.

27. Petyaev IM, Zigangirova NA, Morgunova EY, Kyle NH, Fedina ED, Bashmakov YK. Chlamydia trachomatis growth and cytokine mRNA response in a prostate cancer cell line. Adv Urol. 2019;2019.

28. Yow MA, Tabrizi SN, Severi G, Bolton DM, Pedersen J, Longano A, et al. Detection of infectious organisms in archival prostate cancer tissues. BMC Cancer.
2014;14(1):1-5.

29. Sfanos KS, Sauvageot J, Fedor HL, Dick JD, De Marzo AM, Isaacs WB. A molecular analysis of prokaryotic and viral DNA sequences in prostate tissue from patients with prostate cancer indicates the presence of multiple and diverse microorganisms. Prostate. 2008;68(3):306-20.

30. Anttila T, Tenkanen L, Lumme S, Leinonen $\mathrm{M}$, Gislefoss RE, Hallmans G, etal. Chlamydial antibodies and risk of prostate cancer. Cancer Epidemiol Biomarkers Prev. 2005;14(2):385-9.

31. Dillner J, KnektP,BomanJ, Lehtinen M,AfGeijersstam V, Sapp M, et al. Sero-epidemiologal association between human-papillomavirus infection and risk of prostate cancer. Int J Cancer. 1998;75(4):564-7.

32. Dennis LK, Coughlin JA, McKinnon BC, Wells TS, Gaydos CA, Hamsikova E, et al. Sexually transmitted infections and prostate cancer among men in the US military. Cancer Epidemiol Biomarkers Prev. 2009;18(10):2665-71.

33. Sutcliffe S, Giovannucci E, Gaydos CA, Viscidi RP, Jenkins FJ, Zenilman JM, et al. Plasma antibodies against Chlamydia trachomatis, human papillomavirus, and human herpesvirus type 8 in relation to prostate cancer: A prospective study. Cancer Epidemiol Biomarkers Prev. 2007;16(8):1573-80.

34. Skibinski G, Kelly R, Harkiss D, James K. Immunosuppression by human seminal plasma\&extracellular organelles (prostasomes) modulate activity of phagocytic cells. Am J Reprod Immunol. 1992;28(2):97-103.

35. Kelly R. Prostaglandins in primate semen: Biasing the immune system to benefit spermatozoa and virus? Prostaglandins Leukot Essent Fatty Acids. 1997;57(2):113-8.

36. Montecino-RodriguezE,Berent-MaozB,Dorshkind $\mathrm{K}$. Causes, consequences, and reversal of immune system aging. J Clin Invest. 2013;123(3):958-65. 